Chapter 11

\title{
Recent Advances in the Science and Technology of Desulfurization of Diesel Fuel Using Ionic Liquids
}

\author{
Elaheh Kowsari \\ Additional information is available at the end of the chapter \\ http://dx.doi.org/10.5772/51651
}

\section{Introduction}

Sulfur-containing compounds in transportation fuels are converted by combustion to $\mathrm{SO}_{\mathrm{x}^{\prime}}$ which is a major source of acid rain and air pollution [1]. For environmental protection purposes, many countries have mandated a reduction in fuels sulfur level down to $10 \mathrm{ppm}$ by 2009 [2,3], and with more and more stringent regulatory constraints, it is a trend to achieve little-to-no sulfur fuels in the next several years.

In the petroleum industry, low-sulfur fuels are often obtained from hydrocracking processes or hydrotreating processes [4]. Although hydrotreating processes have been highly effective for the reduction of sulfur levels, further improvement of the hydrodesulfurization efficiency is limited to increasingly severe operational conditions at escalated cost. Moreover, when the deep hydrodesulfurization of motor fuels is needed, not only the energy and hydrogen consumption will be evidently increased, but undesired side reactions (such as the saturation of more olefins) also will be induced. Such side reactions result in a decrease in the octane number of the gasoline.

Ionic liquids, a new class of green solvents, have recently been undergoing intensive research on the removal of thiophenic sulfur species (e.g., dibenzothiophene) from fuels because of the limitation of the traditional hydrodesulfurization method in removing these species. Ionic liquids have the ability of extracting aromatic sulfur-containing compounds at ambient conditions without $\mathrm{H}_{2}$ consumption. In addition Ionic liquids are immiscible with fuel, and the used Ionic liquids can be regenerated and recycled by solvent washing or distillation [5-9]. The desulfurization using ionic liquids has received growing attention [10-26].

In 2003, Lo et al. first reported chemical oxidation in conjunction with Ionic liquid extraction

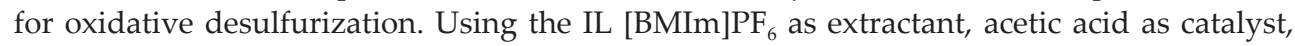


and $\mathrm{H}_{2} \mathrm{O}_{2}$ as oxidant, the sulfur removal of DBT in model oil was increased significantly to $85 \%$. The oxidation of organosulfur compounds to their corresponding sulfones catalyzed by polyoxometallic acids and their salts in Ionic liquids was also reported [27, 28]. Furthermore, it is well-known that homogeneous catalysts are difficult to separate from their reaction products limiting their recyclability. Currently, more efficient ODS systems solely containing $\mathrm{H}_{2} \mathrm{O}_{2}$ as oxidant, acidic ionic liquid, [HMIm] $\mathrm{BF}_{4}$ or $[\mathrm{Hnmp}] \mathrm{BF}_{4}$ as extractant and catalyst have been reported by Lu et al. [29] and Zhao et al.[30] respectively.

Different types of ionic liquids, Imidazolium, pyridinium, and ammonium based Ionic liquids with different anion were demonstrated to be potentially applicable for sulfur removal from transportation fuels. Holbrey et al. [31] investigated the DBT extraction power from dodecan. This study ranks ionic liquids desulfurization ability by cation following the sequence methyl pyridinium $\geq$ pyridinium $\approx$ imidazolium $\approx$ pyrrolidinium with much less significant variation with anion type. Recently, several pyridinium ionic liquids have been investigated for desulfurization-oriented purposes [32, 33]. In this chapter, the removal of sulfur compounds (S-compounds) from diesel fuels with different Ionic liquids are systematically reviewed.

\section{Current Desulfurization Technologies}

\subsection{General Overview}

Diesel fuel is a multi-purpose petroleum fuel used in trucks, trains, boats, buses, planes, heavy machinery and off-road vehicles. It also remains one of the largest sources of fine particle air pollution, which has serious health impacts. Besides fine particles or soot, Dieselfueled engines also emit nitrogen oxides that can form ground level ozone.

Beginning in 2001, the U.S. Environmental Protection Agency (EPA) passed rules requiring use of ultra-low sulfur diesel (ULSD) fuel in diesel engines like trucks and buses, construction equipment, and more recently, stationary sources. Ultra-low sulfur diesel (ULSD) has only 15 parts per million (ppm) of sulfur. Low sulfur fuel has 500 ppm sulfur and uncontrolled sulfur diesel may have levels much higher [34-37].

The use of ULSD fuel in conjunction with re-designed advanced emission-control devices lowers the levels of released hydrocarbons, sulfur and nitrogen compounds, along with harmful particulate matter, to almost zero. Nitrogen oxides chemically react to form a lower-atmosphere ozone layer and contribute to acid rain. Burning ULSD fuel greatly cuts the amount of sulfur dioxide, a major contributor to acid rain. The oxides rise high into the atmosphere, lowering the $\mathrm{pH}$ of rain drops.

\subsection{Description of Hydrodesulfurization (HDS) Process}

Hydrodesulfurization (HDS) also know as a hydrotreating process, is one of the most common desulfurization methods that have been used in refinery processes, since the 
1950s. HDS is a catalytic chemical process widely used to remove sulfur (S) from natural gas and from refined petroleum products such as gasoline or petrol, jet fuel, kerosene, diesel fuel, and fuel oils. The purpose of removing the sulfur is to reduce the sulfur dioxide $\left(\mathrm{SO}_{2}\right)$ emissions that result from using those fuels in automotive vehicles, aircraft, railroad locomotives, ships, gas or oil burning power plants, residential and industrial furnaces, and other forms of fuel combustion.

The industrial hydrodesulfurization processes include facilities for the capture and removal of the resulting hydrogen sulfide $\left(\mathrm{H}_{2} \mathrm{~S}\right)$ gas. In petroleum refineries, the hydrogen sulfide gas is then subsequently converted into byproduct elemental sulfur or sulfuric acid $\left(\mathrm{H}_{2} \mathrm{SO} 4\right)$. In fact, the vast majority of the 64,000,000 metric tons of sulfur produced worldwide in 2005 was byproduct sulfur from refineries and other hydrocarbon processing plants. Sulfur contents in crude oil may be categorized to the following groups [38]:

1- Free Elemental Sulfur

2- Mercaptans \& Tiols (R-SH)

3- Hydrogen Sulfide

4- Sulfides

5- Disulfides (R-S-S-R')

6- Poly Sulfides $\left(\mathrm{R}-\mathrm{S}_{\mathrm{n}}-\mathrm{R}^{\prime}\right)$

7- Thiophenes and their derivatives such as BT and DBT

In a typical catalytic hydrodesulfurization unit, the feedstock is deaerated and mixed with hydrogen, preheated in a fired heater $\left(600^{\circ}-800^{\circ} \mathrm{F}\right)$ and then charged under pressure (up to 1,000 psi) through a fixed-bed catalytic reactor

Although HDS, a high-pressure, high-temperature catalytic process that converts organic sulfur to hydrogen sulfide gas, can remove various types of sulfur compounds, some types of heterocyclic sulfur compounds existing in petroleum cannot be removed [39].

\subsection{Biodesulfurization (BDS)}

Biodesulfurization (BDS), based on the application of microorganisms that selectively remove sulfur atoms from organosulfur compounds, appears as a viable technology to complement the traditional hydrodesulfurization of fuels.

Enzymes in the bacteria selectively oxidize the sulfur, then cleave carbon-sulfur bonds. BDS will operate at ambient temperatures and atmospheric pressure and thus will require substantially less energy than conventional HDS methods to achieve sulfur levels below those required by current regulatory standards. BDS generates a fraction of the $\mathrm{CO}_{2}$ that is generated in association with HDS, and it does not require hydrogen. Additionally, BDS can effectively remove some key sulfur-containing compounds that are among the most difficult for HDS to treat. BDS can be used instead of, or complementary with, HDS [40-52]. 


\subsection{Oxidative Desulfurization (ODS)}

Oxidative desulfurization is considered as the latest unconventional desulfurization process which involves chemical oxidation of divalent organic sulfur compounds to the corresponding hexavalent sulfur, also known as sulfone[53-61].

\subsection{Adsorptive Desulfurization (ADS)}

In adsorptive desulfurization process, OSCs are adsorbed into a specified solid adsorbent so as to produce none- or low-sulfur fuel. Depending onthe interaction between OSCs and the adsorbent, adsorptive desulfurization can be classified into direct adsorption desulfurization and reactive adsorption desulfurization [62].

\section{Desulfurization of diesel fuels by extraction with ionic liquids}

\subsection{Desulfurization of diesel fuels by extraction with N-alkyl-pyridinium-based ionic liquids}

3-Methylpyridinium-based ionic liquids were demonstrated to be effective for the selective removal of aromatic heterocyclic sulfur compounds from diesel at room temperature by Gao and coworkers [32]. The results indicated that the extractive performance using 3methylpyridinium-based ionic liquids followed the order of 1-octyl-3-methylpyridinium tetrafluoroborate $\left(\left[\mathrm{C}_{8}{ }^{3} \mathrm{MPy}\right]\left[\mathrm{BF}_{4}\right]\right)>$ 1-hexyl-3-methylpyridinium tetrafluoroborate $\left(\left[\mathrm{C}_{6}\right.\right.$ $\left.\left.{ }^{3} \mathrm{MPy}\right]\left[\mathrm{BF}_{4}\right]\right)>$ 1-butyl-3-methylpyridinium tetrafluoroborate $\left(\left[\mathrm{C}_{4}{ }^{3} \mathrm{MPy}\right]\left[\mathrm{BF}_{4}\right]\right)$. For a given IL, the sulfur removal selectivity of sulfur compounds followed the order of dibenzothiophene $(\mathrm{DBT})>$ benzothiophene $(\mathrm{BT})>$ thiophene $(\mathrm{TS})>$ 4,6-dibenzothiophene $(4,6-$ $\mathrm{DMDBT}$ ) under the same conditions, except for $\left[\mathrm{C}^{3} \mathrm{MPy}\right]\left[\mathrm{BF}_{4}\right]$ ionic liquid, which followed the order of DBT > BT > 4,6-DMDBT > TS. The 3-methylpyridinium-based ionic liquids are insoluble in diesel while diesel has a certain solubility in 3-methylpyridiniumbased ionic liquids, with the content varying from $6.1 \mathrm{wt} \%$ for $\left[\mathrm{C}_{4}{ }^{3} \mathrm{MPy}\right]\left[\mathrm{BF}_{4}\right]$ to $9.5 \mathrm{wt} \%$ for $\left[\mathrm{C}_{8}{ }^{3} \mathrm{MPy}\right]\left[\mathrm{BF}_{4}\right]$. The spent ionic liquid saturated sulfur compounds could be regenerated by a water dilution process. Considering these results, ionic liquids studied in this work are more competitive and feasible for extractive desulfurization applications. Moreover, the extractive desulfurization using 3-methylpyridinium-based ionic liquids could be used at least as a complementary process to hydrodesulfurization (HDS).

The pyridinium-based ionic liquids are employed as phase-transfer catalysts (PTCs) for phase-transfer catalytic oxidation of dibenzothiophene (DBT) dissolved in n-octane by D. Zhao and coworkers [63]. The partition coefficients of DBT between ionic liquids and n-octane are investigated. Then $\mathrm{H}_{2} \mathrm{O}_{2}$-formic acid is used as an oxidant and ionic liquids are used as PTCs. The reaction turns to be heterogeneous and desulfurization rate of DBT increased apparently. When IL ([BPy] $\left.\mathrm{HSO}_{4}\right)$ is used as PTC, and the condition are: temperature is $60{ }^{\circ} \mathrm{C}$, time is $60 \mathrm{~min}, \mathrm{H}_{2} \mathrm{O}_{2}$ /sulfur molar ratio $(\mathrm{O} / \mathrm{S})$ is 4 , the desulfurization rate reaches the maximum $(93.3 \%)$, and the desulfurization of the real gasoline is also investigat- 
ed, $87.7 \%$ of sulfur contents are removed under optima reaction conditions. The PTC $[\mathrm{BPy}] \mathrm{HSO}_{4}$ can be recycled for five times without significant decrease in activity. The ability of the ionic liquids to extract DBT from oil phase follows the order below: [BPy $\mathrm{HSO}_{4}>[\mathrm{BPy}] \mathrm{H}_{2} \mathrm{PO}_{4}>[\mathrm{BPy}] \mathrm{SCN}>[\mathrm{BPy}] \mathrm{BF}_{4}$. The ionic liquid $[\mathrm{BPy}] \mathrm{HSO}_{4}$ has the highest $\mathrm{KN}$ value 1.42 , followed by the ionic liquid $[\mathrm{BPy}] \mathrm{H}_{2} \mathrm{PO}_{4}$, the $\mathrm{KN}$ value is 1.24 . figure 1 is shown oxidization mechanism of DBT using ionic liquid as phase-transfer catalyst.

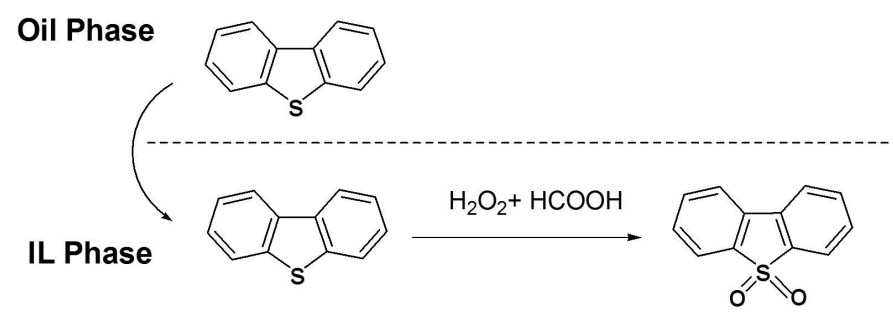

Figure 1. Oxidization mechanism of DBT using ionic liquid as phase-transfer scatalyst.

[Reproduced from Zhao D, Wang Y, Duan E, Zhang J. Oxidation Desulfurization of Fuel using Pyridinium-Based lonic Liquids as Phase-Transfer Catalysts. Fuel Proces Tech. 2010; 91(12):1803-1806, Copyright (2010), with permeation from Elsevier]

Suitability of a pyridinium ionic liquid as a solvent in desulfurization has been analyzed by Arce and coworkers [64]. (Liquid + liquid )equilibria for ternary systems composed by 1-hexyl-3,5-dimethyl pyridinium \{bis[trifluoromethylsulfonyl] imide, thiophene, and three hydrocarbons representative of fuel (n-heptane, 2,2,4 trimethylpentane, and toluene) have been determined at $\mathrm{T}=298.15 \mathrm{~K}$ and atmospheric pressure. High solubility of thiophene in the ionic liquid and also of toluene have been found, being this solvent practically immiscible with 2,2,4 trimethylpentane and heptane. The chemical structure of [hmmpy] [NTf2] was shown in figure 2.

Six N-alkyl-pyridinium-based ILs, N-butyl-pyridinium nitrate $\left([\mathrm{BPy}] \mathrm{NO}_{3}\right), \mathrm{N}$-ethyl-pyridinium nitrate ([EPy] $\left.\mathrm{NO}_{3}\right), \mathrm{N}$-butyl-pyridinium tetrafluoroborate ([BPy] $\left.\mathrm{BF}_{4}\right), \mathrm{N}$-ethyl-pyridinium tetrafluoroborate $\left(\left[\mathrm{EPy}_{\mathrm{B}} \mathrm{BF}_{4}\right), \mathrm{N}\right.$-ethyl-pyridinium acetate ([EPy]Ac), and N-butyl-pyridinium acetate $([\mathrm{BPy}] \mathrm{Ac})$, were prepared and tested in the extraction desulfurization of gasoline ny wang and coworkers [65]. It is found that $\left[\mathrm{BPy} \mathrm{BF}_{4}\right.$ has the best effect on the selective removal of sulfur-containing compounds from gasoline at room temperature among these ionic liquids. The extraction rate of $\left[\mathrm{BPy} \mathrm{BF}_{4}\right.$ is $45.5 \%$. The desulfurization effect of [ $\left.\mathrm{EPy}\right] \mathrm{BF}_{4}$ is the lowest. The used ILs can be regenerated by rotary evaporation or re-extraction using tetrachloromethane. Thermosolvatochromism has been studied in three series of ionic liquids, pyridinium-based 1-butylpyridinium, 1-hexylpyridinium, and 1-octylpyridinium with bis(trifluoromethylsulfonyl) imide [NTf2] and tetrafluoroborate [BF4] anions, pyrrolidiniumbased ionic liquids 1-methyl-1-butylpyrrolidium, 1-methyl-1-hexylpyrrolidium, 1-methyl-1octylpyrrolidium with bis(trifluoromethylsulfonyl) imide anion and phosphonium-based ionic liquids tetrabutylphosphonium with alanate and valinate anions by Khupse and cowork- 
ers [66]. The effect of increase in alkyl chain length and temperature on normalized polarity ET N, Kamlet-Taft parameters, hydrogen bond donor ability (R), hydrogen bond acceptor ability (), and polarizability $\left(\pi^{*}\right)$ was investigated in the temperature range of $298-353 \mathrm{~K}$.

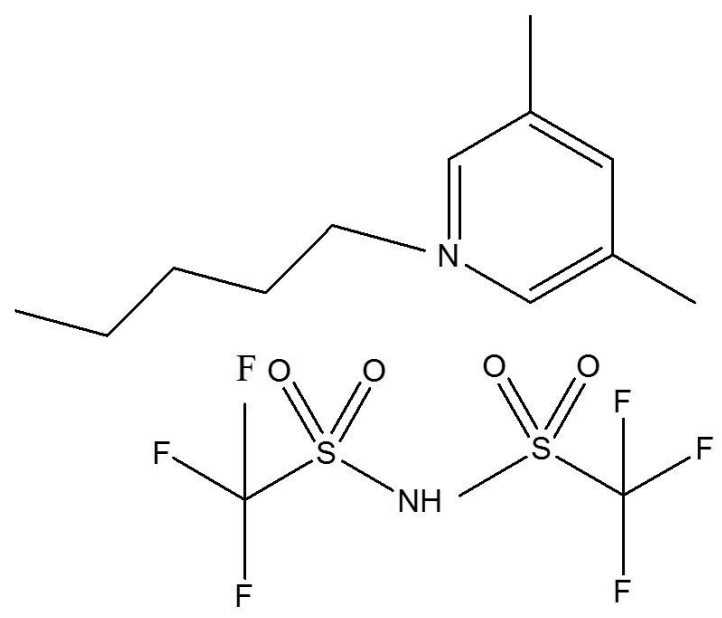

Figure 2. Chemical structure of ionic liquid [hmmpy][NTf $\mathrm{N}_{2}$. No permitiobn.

[Reproduced from Arce A, Francisco M, Soto A, Evaluation of the Polysubstituted Pyridinium Ionic Liquid [hmmpy] [Ntf2] as a Suitable Solvent for Desulfurization: Phase Equilibria. J. Chem. Thermodynamics 2010; 42(6): 712-718, Copyright (2010), with permeation from Elsevier]

Interestingly, the polarity decreases with temperature in the case of pyridinium- and pyrrolidinium-based ionic liquids, and it increases with temperature in the case of phosphoniumbased ionic liquids.

\subsection{Desulfurization of of fuel Using Imidazolium-based ILs}

$\mathrm{N}$-butylimidazole-derived dialkylphosphate ionic liquids are demonstrated to be effective for extractive removal of aromatic sulfur compounds (S-compounds) from fuel oils by Nie and coworkers [67], and show strong preferential extraction for aromatic S-compound versus toluene. Sulfur partition coefficients (KN) between ionic liquid and fuel oil at $298.15 \mathrm{~K}$ are determined experimentally over a wide range of sulfur content. The results show that the sulfur removal selectivity for a specific ionic liquid is dependent on the molecular structure of the S-compounds and follows the order dibenzothiophene >benzothiophene>thiophene >3-methylthiophene, and the efficiency of the ionic liquids for removal of aromatic Scompounds is dependent on the size and structure of both cations and anions of the ionic liquids. For the dialkylphosphate ionic liquids studied with the same anion, the longer the alkyl substitute to the imidazolium ring is the higher the $\mathrm{KN}$ value for that ionic liquid, and a similar trend is found for the ionic liquids with same cation. The chemical structures of ionic liquids were shown in figure 3. 

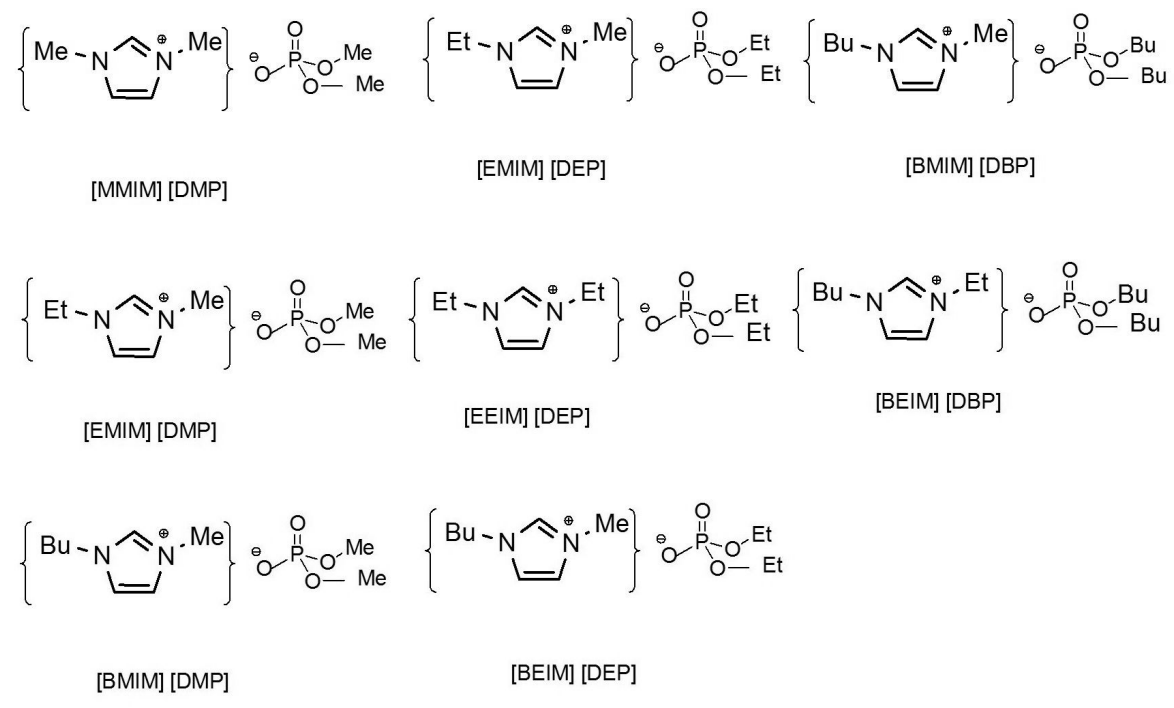

Figure 3. Structures of $N, N$-dialkylimidazolium dialkylphosphate ionic liquids.

[Reproduced from Nie Y, Li C, Meng H, Wang Z. N,N-Dialkylimidazolium Dialkylphosphate lonic Liquids: Their Extractive Performance for Thiophene Series Compounds from Fuel Oils Versus the Length of Alkyl Group. Fuel Proces Tech. 2008; 89 (10): 978 -983, Copyright (2008), with permeation from Elsevier]

Two types of ionic liquids, 1-alkyl-3-methylimidazolium [AMIM] tetrafluoroborate and hexafluorophosphate and trimethylamine hydrochloride $\left(\mathrm{AlCl}_{3}-\mathrm{TMAC}\right)$, were demonstrated to be potentially applicable for sulfur removal from transportation fuels by Zhang and Coworkers [68]. $\mathrm{EMIMBF}_{4}$ (E ) ethyl), $\mathrm{BMIMPF}_{6}$ (B ) butyl), BMIMBF 4 , and heavier AMIMPF 6 showed high selectivity, particularly toward aromatic sulfur and nitrogen compounds, for extractive desulfurization and denitrogenation.

The used ionic liquids were readily regenerated either by distillation or by water displacement of absorbed molecules. The absorbed aromatic S-containing compounds were quantitatively recovered. Organic compounds with higher aromatic ठ-electron density were favorably absorbed. Alkyl substitution on the aromatic rings was found to significantly reduce the absorption capacity, as a result of a steric effect. The cation and anion structure and size in the ionic liquids are important parameters affecting the absorption capacity for aromatic compounds. At low concentrations, the N- and S-containing compounds were extracted from fuels without mutual hindrance. $\mathrm{AlCl}_{3}$-TMAC ionic liquids were found to have remarkably high absorption capacities for aromatics.

To develop an advanced desulfurization process that can be carried out under mild conditions without pressurized hydrogen or catalysis that has been evaluated for the extraction of thiophenic sulfur from a model fuel using the ionic liquids, 1-alkyl-3-alkyl imidazolium alkyl sulfate at room temperature was investigated by Mochizuki [69]. 
Six types of halogen-free ionic liquids with different alkyl chain lengths were prepared. The extraction yield of dibenzothiophene was higher than that of diphenylsulfide and diphenyldisulfide. The extraction yield of dibenzothiophene increased linearly with an increase in the length of alkyl chains and the mass ratio of the ionic liquid to the model fuel. The effect because of the change in the type of solvent was not appreciable, and dibenzothiophene was efficiently removed regardless of whether tetralin, benzene, or n-dodecane was used as the solvent.

The extractive and oxidative deep desulfurizations of model fuel oils using a low-viscosity ionic liquids, i.e.,1-ethyl-3-methylimidazolium dicyanamide $\left(\left[\mathrm{C}_{2} \mathrm{mim}\right]\left[\mathrm{N}(\mathrm{CN})_{2}\right]\right)$, are investigated by $\mathrm{Yu}$ and coworkers [70]. [ $\left.\mathrm{C}_{2} \mathrm{mim}\right]\left[\mathrm{N}(\mathrm{CN})_{2}\right]$ is capable of effectively extracting thiophene (TS) and dibenzothiophene (DBT) from oils. The sulfur content in the raffinate phases is only $\sim 10$ ppm after a few extraction steps. A short extraction equilibrium time of $<5 \mathrm{~min}$ is observed.

The extraction operation is insensitive to temperature, and it can be effectively performed at or around room temperature. Unexpectedly, the oxidative removal of DBT by such a dicyanamide-based ionic liquid is not effective and is not as good as the corresponding extraction operation. Such an undesirable oxidative desulfurization is understood at a molecular level from ab initio calculations, and it may be ascribed to the strong intermolecular interaction between $\mathrm{CH}_{3} \mathrm{COOH}$ or $\mathrm{CH}_{3} \mathrm{COOOH}$ and $\left[\mathrm{C}_{2} \mathrm{mim}\right]\left[\mathrm{N}(\mathrm{CN})_{2}\right]$ phase. Therefore, such a dicyanamide-based ionic liquid is efficient for direct extractive desulfurization, while it is less efficient for oxidative desulfurization.

An extraction and catalytic oxidation desulfurization (ECODS) system composed of $\mathrm{V}_{2} \mathrm{O}_{5}, 30$ ${ }_{w t} \% \mathrm{H}_{2} \mathrm{O}_{2}$ and 1-butyl-3-methylimidazolium tetrafluoroborate $\left(\left[\mathrm{Bmim}^{-} \mathrm{BF}_{4}\right)\right.$ as the basic experiment was used for the removal of DBT from the model oil at moderate temperature (30 ${ }^{\circ} \mathrm{C}$ ) by $\mathrm{Xu}$ and coworkers [71]. In the reaction process, $\mathrm{V}_{2} \mathrm{O}_{5}$ was oxidized by $\mathrm{H}_{2} \mathrm{O}_{2}$ into peroxovanadium compounds. Meanwhile, the sulfur-containing compounds, such as benzothiophene (BT), dibenzothiophene (DBT), and 4,6-dimethyldibenzothiophene (4,6-DMDBT), were extracted into ionic liquid from the model oil and oxidized into their corresponding sulfones by peroxovanadium compounds. The reactivity of sulfur-containing compounds in the ECODS followed this order: DBT>BT>4,6-DMDBT. In the case of ECODS, the sulfur removal of DBT can reach $98.7 \%$, which was superior to that of the simple extraction with IL $(16.5 \%)$ or the catalytic oxidation $(2.8 \%)$. This ECODS system could be recycled seven times without a significant decrease in activity. Supposed Mechanism of the Deep ECODS Using $\mathrm{V}_{2} \mathrm{O}_{5}$ Catalyst in ionic liquid shows in figure 4 .

In order to obtain the ultra low-sulfur diesel, deep desulfurization of diesel oil has become a vital subject of environmental catalysis studies. Extraction and catalytic oxidation desulfurization (ECODS) system is one of the most promising desulfurization processes. A series of Keggin-type POM-based ionic liquids hybrid materials [MIMPS $]_{3} \mathrm{PW}_{12} \mathrm{O}_{40} 2 \mathrm{H}_{2} \mathrm{O}$ (1-(3-sulfonic group) propyl-3-methyl imidazolium phosphotungstate), [Bmim $]_{3} \mathrm{PW}_{12} \mathrm{O}_{40}$ (1-butyl 3-methyl imidazolium phosphotungstate), [Bmim $]_{3} \mathrm{PMo}_{12} \mathrm{O}_{40}$ (1-butyl 3-methyl imidazolium phosphomolybdate) and [Bmim $]_{4} \mathrm{SiW}_{12} \mathrm{O}_{40}$ (1-butyl-3-methyl imidazolium silicotungstate) have been developed in this study, and the reaction has performed using the POM-ILs materials as catalysts, $\mathrm{H}_{2} \mathrm{O}_{2}$ as oxidant, and ionic liquid (IL) as solvent by Zhu and coworkers [72]. Through ex- 
perimental evaluations, [MIMPS $]_{3} \mathrm{PW}_{12} \mathrm{O}_{40} 2 \mathrm{H}_{2} \mathrm{O}$ was found to be the best catalyst, with an Sremoval of $100 \%$ at $30^{\circ} \mathrm{C}$ for $1 \mathrm{~h}$. The main factors affecting the process including temperature, catalyst dosage, and $\mathrm{O} / \mathrm{S}\left(\mathrm{H}_{2} \mathrm{O}_{2} / \mathrm{DBT}\right)$ molar ratio were investigated in detail. Under the optimal conditions, DBT (dibenzothiophene) and 4,6-DMDBT (4,6-dimethyl-dibenzothiophene)could achieve high desulfurization efficiency. Moreover, the reaction system also exhibited high activity in actual diesel oil, which could be reduced from 1113 ppm to 198 ppm. The reaction system could recycle 8-times with a slight decrease in activity.

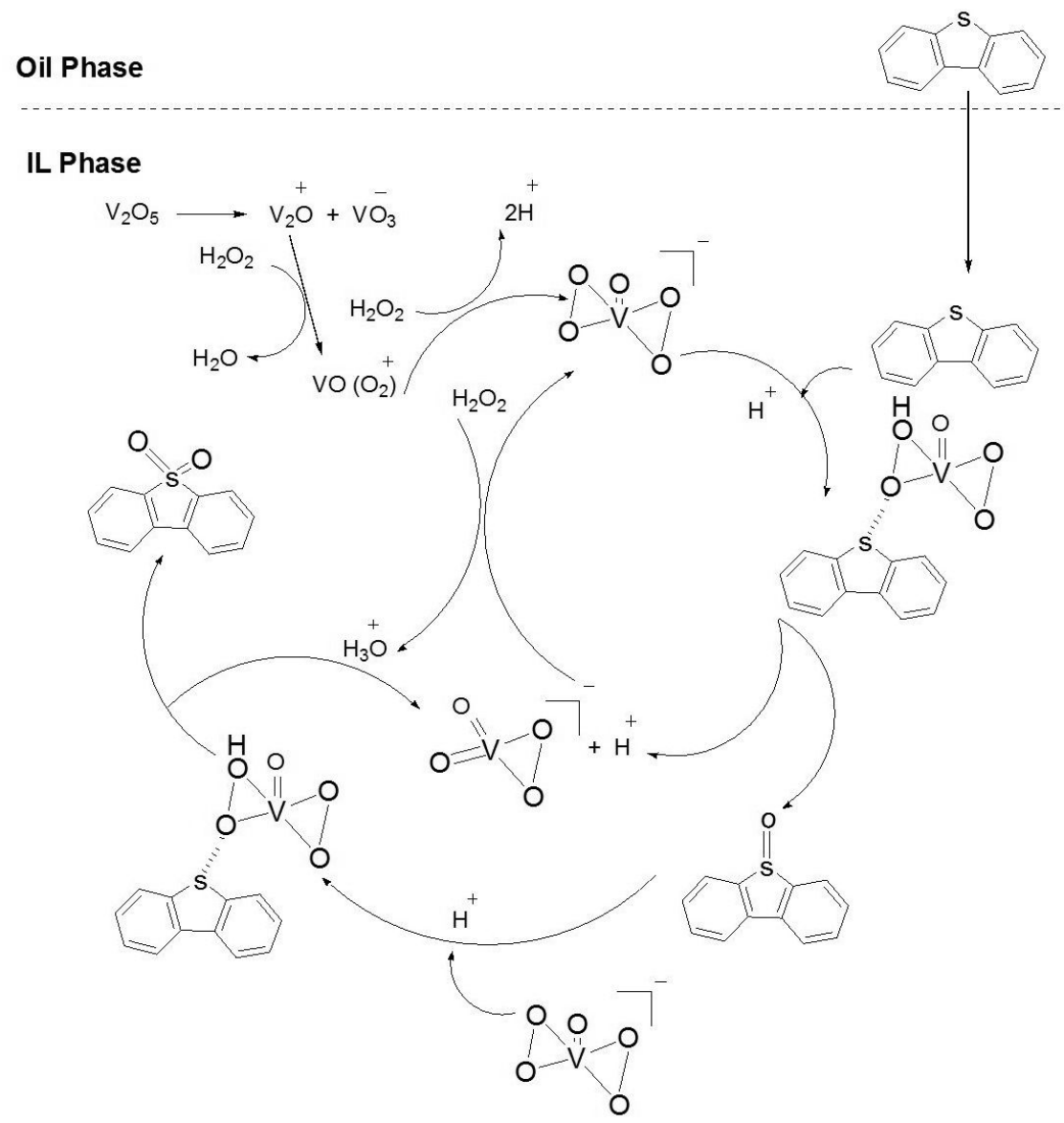

Figure 4. Supposed Mechanism of the Deep ECODS Using $\mathrm{V}_{2} \mathrm{O}_{5}$ Catalyst in ionic liquid.

[Reproduced from Xu D, Zhu W, Li H, Zhang J, Zou F, Shi H, Yan Y. Oxidative Desulfurization of Fuels Catalyzed by $\mathrm{V}_{2} \mathrm{O}_{5}$ in Ionic Liquids at Room Temperature. Energy Fuels 2009; 23(12): 5929-5933, Copyright (2009), with permeation from American Chemical Society] 
Ozone associated with hydrogen peroxide as an advanced oxidation process had been employed to remove dibenzothiophene (DBT) in model oil in an ionic liquid system by Wang and coworkers [73]. DBT was oxidized availably by ozone and hydroxyl radicals that were generated by ozone and hydrogen peroxide. The oxidative productions of DBT were extracted to the IL phase because of their high polarity. The IL can be recycled 5 times without a significant decrease in desulfurization activity.

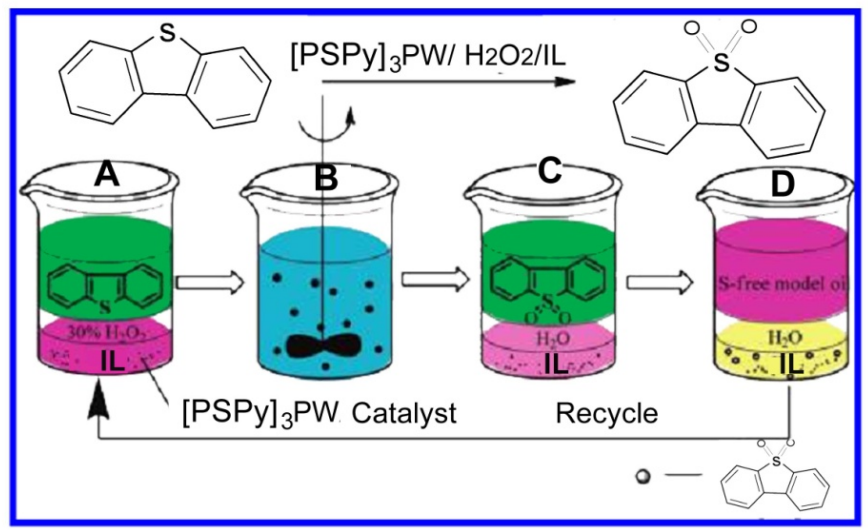

Figure 5. Catalytic Oxidation and Extraction of Sulfur Content Present in Model Oil: (A) before Oxidation; (B) during Oxidation; (C) after Oxidation; (D) with Extraction of Oxidative.

[Reproduced from Huang W, Zhu W, Li H, Shi H, Zhu G, Liu H, Chen G. Heteropolyanion-Based lonic Liquid for Deep Desulfurization of Fuels in Ionic Liquids, Ind. Eng. Chem. Res. 2010, 49(19):8998-9003.Copyright (2010), with permeation from American Chemical ociety]

Peroxotungsten and peroxomolybdenum complexes such as $\left[\mathrm{WO}\left(\mathrm{O}_{2}\right)_{2}\right.$. Phen. $\left.\mathrm{H}_{2} \mathrm{O}\right]$ and [MoO $\left(\mathrm{O}_{2}\right)_{2}$.Phen] (Phen: 1,10-phenanthroline) have been synthesized and characterized and were immobilized in 1-butyl-3-methylimidazolium tetrafluoroborate ([Bmim] $\left.\mathrm{BF}_{4}\right), 1-\mathrm{n}$ octyl-3-methylimidazolium tetrafluoroborate ([Omim]-BF ${ }_{4}$, 1-butyl-3-methyl-imidazolium hexafluorophosphate $\left(\left[\mathrm{Bmim} \mathrm{PF}_{6}\right)\right.$, and 1-n-octyl-3-methylimidazolium hexafluorophosphate $\left([\mathrm{Omim}] \mathrm{PF}_{6}\right)$ for extraction and catalytic oxidation of dibenzothiophene (DBT) remaining in n-octane by Zhu and coworkers [27]. The results demonstrated that ionic liquid was only used as an extractant for DBT-containing model oil and the removal of sulfur was only about $12.2-22.0 \%$. After addition of 30 wt $\% \mathrm{H}_{2} \mathrm{O}_{2}$ in IL, model oil with $30.0-63.0 \%$ sulfur removal was given via chemical oxidation. While $\mathrm{H}_{2} \mathrm{O}_{2}$ and catalyst were introduced together, the removal of sulfur increased sharply. In the case of the system containing $\mathrm{H}_{2} \mathrm{O}_{2}, \mathrm{WO}\left(\mathrm{O}_{2}\right)_{2}$. Phen. $\mathrm{H}_{2} \mathrm{O}$ and $\left[\mathrm{Bmim}_{3} \mathrm{BF}_{4}\right.$, extraction and catalytic oxidation increased the sulfur removal to $98.6 \%$. However, the oxidative desulfurization systems containing $\mathrm{WO}\left(\mathrm{O}_{2}\right)_{2}$. Phen. $\mathrm{H}_{2} \mathrm{O}$ and $\mathrm{H}_{2} \mathrm{O}_{2}$ only led to $50.3 \%$ sulfur removal in the absence of ionic liquid. This experiment demonstrated that a combination of catalytic oxidation and extraction in ionic liquid can deeply remove DBT from model oil. This result 
also indicated the remarkable advantage of this process over the desulfurization by mere solvent extraction with ionic liquid or catalytic oxidation without ionic liquid.

A heteropolyanion-based ionic liquid, [(3-sulfonic acid) propylpyridine $]_{3} \mathrm{PW}_{12} \mathrm{O}_{40} 2 \mathrm{H}_{2} \mathrm{O}$, $[\mathrm{PSPy}]_{3} \mathrm{PW}_{12} \mathrm{O}_{40} 2 \mathrm{H}_{2} \mathrm{O}$, abbreviated [PSPy $]_{3} \mathrm{PW}$, was synthesized and approved as an effective catalyst for desulfurization of fuels in [omim] $\mathrm{PF}_{6}$ by using aqueous $\mathrm{H}_{2} \mathrm{O}_{2}$ as oxidant by Huang and coworkers [74]. The catalysis was fulfilled with advantages of high activity, simplified workup, and flexible recyclability. The catalytic oxidation reactivity of sulfur-containing compounds was in the order dibenzothiophene (DBT) $>4,6$-dimethyldibenzothiophene $(4,6-\mathrm{DMDBT})>$ benzothiophene (BT). The effects of the amount of $[\mathrm{PSPy}]_{3} \mathrm{PW}, \mathrm{H}_{2} \mathrm{O}_{2}$, and reaction time and temperature were investigated in detail. Under the optimal conditions, the removal of DBT achieved 99.4\%. Especially, we found that the removal of 4,6-DMDBT could be up to $98.8 \%$, and the system could be recycled at least 9 times without significant decrease in activity. The sulfur level of FCC gasoline could be reduced from 360 to $70 \mathrm{ppm}$ in the extraction and catalytic oxidation system. Catalytic Oxidation and Extraction of Sulfur Content Present in Model Oil shows in figure 5.

\subsection{Desulfurization of fuel using quaternary ammonium -based ionic liquids}

With the aim of deep desulfurization of the gasoline, an amphiphilic catalyst, which is composed of lacunary anion $\left[\mathrm{PW}_{11} \mathrm{O}_{39}\right]^{7-}$ and quaternary ammonium cation $\left[\mathrm{C}_{18} \mathrm{H}_{37}\left(\mathrm{CH}_{3}\right)_{3}\right] \mathrm{N}^{+}$, assembled in hydrophobic ionic liquid emulsions, can oxidize the sulfur compounds present in oil into their corresponding sulfones under ambient reaction conditions by Ge and coworkers [75].

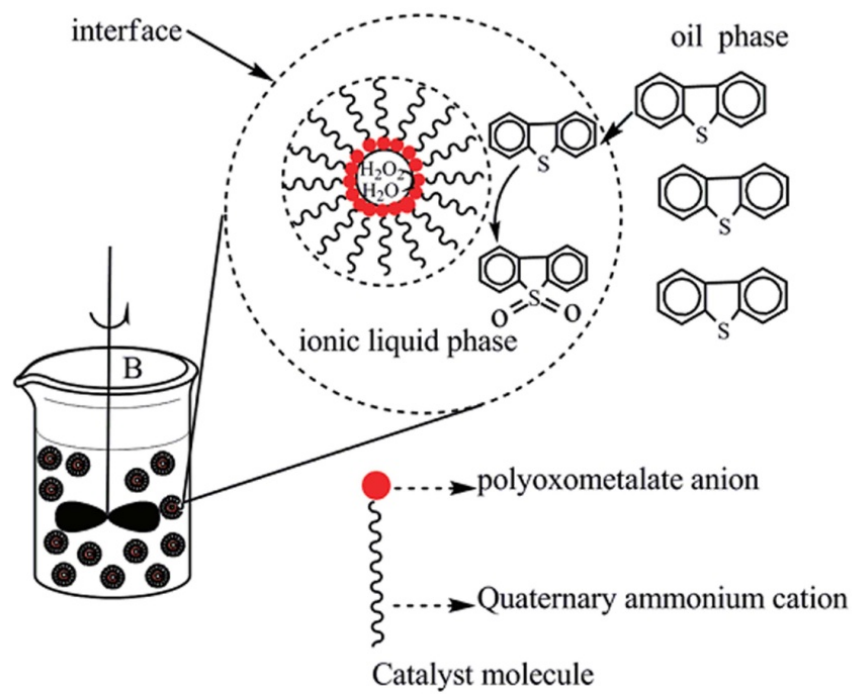

Figure 6. Catalytic Oxidation of DBT in Ionic Liquid Emulsion System. 
[Reproduced from Ge J, Zhou Y, Yang Y, Xue M. Catalytic Oxidative Desulfurization of Gasoline Using lonic Liquid Emulsion System. Ind. Eng. Chem. Res. 2011; 50(24): 13686-13692, Copyright (2011), with permeation from American Chemical Society]

In this process, catalytic oxidation of sulfur-containing molecules in model oil was investigated in detail under di ' erent reaction conditions (including di ' erent desulfurization systems, $\mathrm{H}_{2} \mathrm{O}_{2}$ /DBT molar ratio, temperature, and various sulfur compounds). Moreover; this ionic liquid emulsion systemcould be recycled five times with an unnoticeable decrease in catalytic activity, and, fromthe kinetics study, it can be shown that the catalytic oxidative reaction is a pseudofirst-order reaction and the half-life is 30.4 min. Furthermore, the mechanism of catalytic oxidation desulfurization was elaborated, and the total sulfur level of real gasoline can be decreased from 1236 to 65 ppm after catalytic oxidation using an ionic liquid emulsion system.

In this emulsion reaction system, the catalystmolecule acts as an emulsifying agent, could be uniformly distributed in the interface of $\mathrm{H}_{2} \mathrm{O}_{2}$ ionic liquid, and forms a film around the dispersed ionic liquid droplets (Scheme 1)

\subsection{Extractive Desulfurization Using Fe-Containing Ionic Liquids}

$\mathrm{Fe}^{\mathrm{III}}$-containing ionic liquids, prepared from the reaction of anhydrous $\mathrm{FeCl}_{3}$ and imidazolium chloride ([imidazolium]Cl), were used as effective extractants for the desulfurization of a model oil containing dibenzothiophene (DBT) by Ko and coworkers [76]. The amount of DBT extracted increased with an increasing molar ratio of $\mathrm{FeCl}_{3} /$ imidazolium] $\mathrm{Cl}$. The ability of the ionic liquids to extract DBT seems to be attributed to the combined effects of Lewis acidity and fluidity of ionic liquids.

$x \mathrm{Et}_{3} \mathrm{NHCl}_{3} \mathrm{FeCl}_{3}$ ( $\mathrm{x}=1.4-1.8$ ) ionic liquids were synthesized by mixing $\mathrm{Et}_{3} \mathrm{NHCl}$ and anhydrous $\mathrm{FeCl} 3$ at $80^{\circ} \mathrm{C}$ by $\mathrm{Li}$ and coworkers [77]. These were liquid at room temperature, with low viscosities, and exhibited remarkable abilities in effective desulfurization of thiophene in n-octane and fluid catalytic cracking (FCC) gasoline. Among them, $1.6 \mathrm{Et}_{3} \mathrm{NHCl}_{3} \mathrm{FeCl}_{3}$ showed the highest sulfur removal. The anionic species $\mathrm{FeCl}_{4}$-existed in $1.6 \mathrm{Et}_{3} \mathrm{NHCl}_{3} \mathrm{FeCl}_{3}$ ionic liquid, as detected by electrospray ionization-mass spectrometry (ESI-MS), and the ionic liquidwas stable in air andmoisture. Sulfur-free $(<10 \mathrm{mg} / \mathrm{L})$ gasoline could be obtained after extraction twice using an ionic liquid/oil volume ratio of 1 . The ionic liquid could be recycled 10 times by distillation with a slight decrease in activity.The influence of the $\mathrm{Et}_{3} \mathrm{NHCl} / \mathrm{FeCl}_{3}$ molar ratio on the sulfur removal of thiophene is shown in Table 1.

\begin{tabular}{|c|c|c|c|}
\hline $\begin{array}{l}\text { Sulfur } \\
\text { Removal (\%) }\end{array}$ & ionic liquids & $\begin{array}{l}\text { Sulfur } \\
\text { Removal (\%) }\end{array}$ & ionic liquids \\
\hline 41.2 & {$[\mathrm{BMIm}]\left[\mathrm{OcSO}_{4}\right]^{b}$} & 80.2 & $1.4 \mathrm{Et}_{3} \mathrm{NHCl} . \mathrm{Fe} \mathrm{Cl}_{3}$ \\
\hline 40.0 & {$\left[\mathrm{C}_{8} \mathrm{MIm}\right] \mathrm{BF}_{4}{ }^{\mathrm{c}}$} & 84.3 & $1.5 \mathrm{Et}_{3} \mathrm{NHCl} . \mathrm{Fe} \mathrm{Cl}_{3}$ \\
\hline 51.7 & {$\left[\mathrm{C}_{8} \mathrm{MPy}\right] \mathrm{BF}_{4}{ }^{d}$} & 87.6 & 1.6 $\mathrm{Et}_{3} \mathrm{NHCl} . \mathrm{Fe} \mathrm{Cl}_{3}$ \\
\hline
\end{tabular}


Table 1. Sulfur Removal of Thiophene Using ILs.

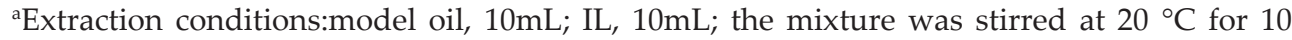
min. ${ }^{b}$ Results from Esser et al. ${ }^{c}$ Results from Alonso et al. ${ }^{d}$ Results from Liu et al.,in which the extraction conditions were mass ratio oil/IL, 1:1; extraction time, $15 \mathrm{~min}$; room temperature. ${ }^{e}$ Results from Liu et al.

[Reproduced from Li FT, Liu Y, Sun ZM, Chen LJ, Zhao DS, Liu RH, Kou CG, Deep Extractive Desulfurization of Gasoline with $x \mathrm{Et}_{3} \mathrm{NHCl}_{3} \mathrm{FeCl}_{3}$ Ionic Liquids. Energy Fuels, 2010; 24(8): 4285-4289, Copyright (2010), with permeation from American Chemical Society]

A series of polymer-supported metal chlorides imidazolium ionic liquid moieties, M/CMPS$\operatorname{Im}(\mathrm{Cl})\left(\mathrm{M}=\mathrm{CuCl}, \mathrm{ZnCl}_{2}\right.$ and $\left.\mathrm{FeCl}_{3}\right)$, were synthesized by grafted method using chloromethylated polystyrene (CMPS) resin as support by Wang and coworkers [78].

The results showed that the surface of CMPS resin was covered with a thin layer of extraction activity components. Then, the synthesized CMPS-supported imidazolium-based ionic liquids were investigated to extract thiophene and its derivatives from model gasoline (n-octane/ thiophene) under certain conditions. For a given imidazolium-based ionic liquid: first, the order of extraction capacity of extractant was $\mathrm{CuCl} / \mathrm{CMPS}-\mathrm{Im}(\mathrm{Cl})>\mathrm{ZnCl} 2 / \mathrm{CMPS}-\mathrm{Im}(\mathrm{Cl})>\mathrm{FeCl}_{3} /$ CMPS- $\operatorname{Im}(\mathrm{Cl})$; the reason for this was that the $\pi$-complexation capability between $\mathrm{Cu}+$ and thiophene was stronger than those of $\mathrm{Fe}^{3+}$ and $\mathrm{Zn}^{2+}$. Second, the sulfur removal selectivity of sulfur compound followed the order of TS $<\mathrm{BT}<\mathrm{DBT}$ under the same conditions; it indicated that the extraction was favored for those aromatic heterocyclic sulfur compounds with higher density aromatic $\pi$-electrons density. Meanwhile, the effect of mass ratio of model gasoline to $\mathrm{M} /$ CMPS- $\operatorname{Im}(\mathrm{Cl})$ ionic liquids, different initial sulfur concentrations, and extraction time on desulfurization rates of M/CMPS-Im $(\mathrm{Cl})$ ionic liquids was performed, respectively.

\subsection{Optimization of oxidative desulfurization of dibenzothiophene using acidic ionic liquid}

The oxidative desulfurization of dibenzothiophene (DBT) in n-octane as model oil with Brönsted acidic ionic liquids $\mathrm{N}$-methyl-pyrrolidonium phosphate $\left([\mathrm{Hnmp}] \mathrm{H}_{2} \mathrm{PO}_{4}\right)$ as catalytic solvent and $\mathrm{H}_{2} \mathrm{O}_{2}$ as oxidant was optimized by orthogonal experiments. $99.8 \%$ of DBT in the model oil was removed under the optimal conditions of molar ratio of $\mathrm{H}_{2} \mathrm{O}_{2}$ to sulfur of $16: 1$, reaction temperature of $60^{\circ} \mathrm{C}$, reaction time of $5 \mathrm{~h}$, and volume ratio of model oil to ionic liquids of 1:1 by ZHAO and coworkers [79]. The desulfurization efficiency of actual diesel was $64.3 \%$ under the optimized conditions. The influences of the desulfurization efficiency of DBT decreased in the following order: oxidation temperature > oxidation time $>$ molar ratio of $\mathrm{H}_{2} \mathrm{O}_{2}$ /sulfur $(\mathrm{O} / \mathrm{S})>$ volume ratio of $[\mathrm{Hnmp}] \mathrm{H}_{2} \mathrm{PO}_{4}$ to model oil (VIL/Vmodel oil), according to extreme analysis of orthogonal test. The ionic liquid $[\mathrm{Hnmp}] \mathrm{H}_{2} \mathrm{PO}_{4}$ can be recycled six times without a significant decrease in activity. 
An acidic ionic liquid N-butyl-N-methylimidazolium hydrogen sulfate ([BMIm] $\mathrm{HSO}_{4}$ ) was applied as extractant and catalyst for the oxidative desulfurization of dibenzothiophenes (DBT) in the presence of $\mathrm{H}_{2} \mathrm{O}_{2}$ in model oil by Zhang and coworkers [80]. Several parameters, e.g., catalyst amount, hydrogen peroxide quantity, reaction time, and temperature, were investigated in detail. The catalytic oxidative desulfurization rate can reach $100 \%$ for DBT in model oil. The ionic liquid $[\mathrm{BMIm}] \mathrm{HSO}_{4}$ can be recycled 5 times with only a slight reduction in activity.

Ionic liquids, a new class of green solvents, have recently been undergoing intensive research on the removal of thiophenic sulfur species (e.g., dibenzothiophene) from fuels because of the limitation of the traditional hydrodesulfurization method in removing these species. In this work, deep oxidative desulfurization of diesel fuels by six functional acidic ionic liquids are studied, in which ionic liquids are used as both extractant and catalyst, and $30 \mathrm{wt} \% \mathrm{H}_{2} \mathrm{O}_{2}$ solution as oxidant by $\mathrm{Yu}$ and coworkers [81]. These ionic liquids include both Lewis acidic species such as 1-butyl-3-methylimidazolium chloride/2 $\mathrm{ZnCl}_{2}\left(\left[\mathrm{C}_{4} \mathrm{mim}\right] \mathrm{Cl} /\right.$ $2 \mathrm{ZnCl}_{2}$ and $\left.\left[\mathrm{C}_{4} \mathrm{mim}\right] \mathrm{Cl} / \mathrm{ZnCl}_{2}\right)$ and Brønsted acidic species such as 1-methyl-3-ethylcarboxylic acid imidazolium hydrogen sulfate $\left(\left[\mathrm{CH}_{2} \mathrm{COOHmim}\right] \mathrm{HSO}_{4}\right)$, 1-methyl-3-(butyl-4sulfinate) imidazolium hydrogen sulfate ([SO3HC4mim] $\left.\mathrm{HSO}_{4}\right),[\mathrm{Hmim}] \mathrm{HSO}_{4}$, and $\left[\mathrm{C}_{4} \mathrm{mim}\right] \mathrm{HSO}_{4}$ where di " erent acidic groups such as $\mathrm{H}, \mathrm{COOH}$, and $\mathrm{SO}_{3} \mathrm{H}$ are appended to the cations. Except for $\left[\mathrm{CH}_{2} \mathrm{COOHmim}\right] \mathrm{HSO}_{4}$, both Brønsted and Lewis acidic ILs are capable of e ectively removing dibenzothiophene from model diesel fuels, where $100 \%$ sulfur removal is obtained for $\left[\mathrm{C}_{4} \mathrm{mim}\right] \mathrm{Cl} / 2 \mathrm{ZnCl}$ and $\left[\mathrm{SO}_{3} \mathrm{HC}_{4}\right.$ mim $] \mathrm{HSO}_{4}$. Thee ' ects of temperature, molar ratio of $\mathrm{O} / \mathrm{S}$, mass ratio of ionic liquid /oil, and ionic liquid regeneration on desulfurization are investigated systematically for $\left[\mathrm{C}_{4} \mathrm{mim}\right] \mathrm{Cl} / 2 \mathrm{ZnCl} \mathrm{Zn}_{2}$ and $\left[\mathrm{SO}_{3} \mathrm{HC}_{4} \mathrm{mim}\right] \mathrm{HSO}_{4}$. The desulfurization ability is not sensitive to themass ratio of IL/oil, which is desired for reducing ionic liquid dosage in industrial application; the ionic liquids can be recycled six times with merely a negligible loss in activity. $\left[\mathrm{C}_{4} \mathrm{mim}\right] \mathrm{Cl} / 2 \mathrm{ZnCl}_{2}$ can reduce the sulfur content in real commercial diesel fuel from 64 to 7.9 ppmwith a sulfur removal of $87.7 \%$; however, it is not too e " ective for coke diesel fuel with high initial sulfur content of 5380 ppm. This work tends to show that diesel fuels can be purified to sulfur-free or ultralow sulfur fuels by further deep oxidative desulfurization by using ionic liquids after hydrodesulfurization. Lewis and Brønsted acidic ionic liquids used in this work show in figure 7. 

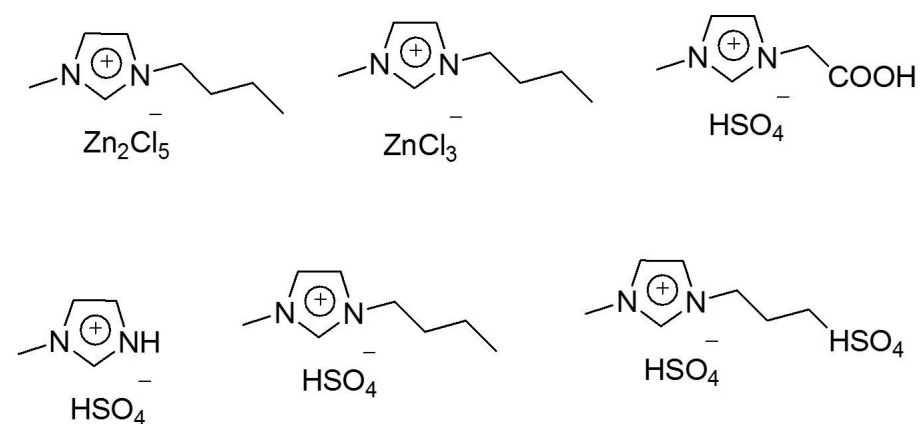

Figure 7. Lewis and Brønsted acidic ionic liquids used in this work.

[Reproduced from Yu G, Zhao J, Song D, Asumana C, Zhang X, Chen X. Deep Oxidative Desulfurization of Diesel Fuels by Acidic lonic Liquids. Ind Eng Chem Res 2011; 50(20): 11690-11697, Copyright (2011), with permeation from American Chemical Society]

\section{Conclusion}

In view of stringent environmental regulations, utilization of sulfur-containing fuel oils has severe limitations regarding emission of sulfur dioxide. Technology for reduction of sulfur in diesel fuel to $15 \mathrm{ppm}$ is currently available and new technologies are under development that could reduce the cost of desulfurization. Chemical oxidation in conjunction with ionic liquid extraction can increase the removal of sulfur sharply. Ionic liquids have the ability of extracting aromatic sulfur-containing compounds at ambient conditions without $\mathrm{H}_{2}$ consumption. The cations, anions structure, and size of ionic liquids are important parameters affecting the extracting ability. In addition ionic liquids are immiscible with fuel, and the used ionic liquids can be regenerated and recycled by solvent washing or distillation.

\section{Author details}

\section{Elaheh Kowsari* $^{*}$}

Address all correspondence to: kowsarie@aut.ac.ir

Department of Chemistry, Amirkabir University of Technology, Tehran, Iran 


\section{References}

[1] Li, H. M., He, L. N., Lu, J. D., Zhu, W. S., Jiang, X., Wang, Y., \& Yan, Y. S. (2009). Deep Oxidative Desulfurization of Fuels Catalyzed by Phosphotungstic Acid in Ionic Liquids at Room Temperature. Energy Fuels, 23(3), 354-357.

[2] Song, CS. (2003). An Overview of New Approaches to Deep Desulfurization for U1tra-Clean Gasoline. Diesel Fuel and Jet Fuel. Catal. Today, 86(1-4), 211-263.

[3] Babich, I. V., \& Moulijn, J. A. (2003). External and Internal Factors Influencing Modern Refineries. Fuel, 82(6), 607-631.

[4] Kwak, C., Lee, J. J., Bae, J. S., Choi, K., \& Moonm, S. H. (2000). Hydrodesulfurization of DBT, 4-MDBT, and 4,6-DMDBT on Fluorinated CoMoS/ $\mathrm{Al}_{2} \mathrm{O}_{3}$ Catalysts. Appl. Catal. A., 200(1), 233-242.

[5] Zhang, SG, \& Zhang, ZC. (2002). Novel Properties of Ionic Liquids in Selective Sulfur Removal from Fuels at Room Temperature. Green Chem., 4, 376-379.

[6] Esser, J., Wasserscheid, P., \& Jess, A. (2004). Deep Desulfurization of Oil Refinery Streams by Extraction with Ionic Liquids. Green Chem., 6, 316-322.

[7] Planeta, J., Karásek, P., \& Roth, M. (2006). Distribution of Sulfur-Containing Aromatics Between [hmim] $\left[\mathrm{Tf}_{2} \mathrm{~N}\right]$ and supercritical $\mathrm{CO}_{2}$ : A Case Study for Deep Desulfurization of Oil Refinery Streams by Extraction WithIonic Liquids. Green Chem., 8, 70-77.

[8] Nie, Y., Li, C. X., \& Wang, Z. H. (2007). Extractive Desulfurization of Fuel Oil Using Alkylimidazole and Its Mixture with Dialkylphosphate Ionic Liquids. Ind. Eng. Chem. Res., 46(15), 5108-5112.

[9] Li, F. T., Liu, R. H., Wen, J. H., Zhao, Sun Z. M., \& Liu, Y. (2009). Desulfurization of Dibenzothiophene by Chemical Oxidation and Solvent Extraction with $\mathrm{Me}_{3} \mathrm{NCH}_{2} \mathrm{C}_{6} \mathrm{H}_{5} \mathrm{Cl} \cdot 2 \mathrm{ZnCl}_{2}$ Ionic Liquid. Green Chem., 11, 883-888.

[10] Zhang, J., Wang, A. J., Li, X., \& Ma, X. H. (2011). Oxidative Desulfurization of Dibenzothiophene and Diesel Over [Bmim $]_{3} \mathrm{PMo}_{12} \mathrm{O}_{40}$. J. Catal., 279(2), 269-275.

[11] Kulkarni, P. S., \& Afonso, C. A. M. (2010). Deep Desulfurization of Diesel Fuel Using Ionic Liquids: Current Status and Future Challenges. Green Chem., 2, 139-149.

[12] Bösmann, A., Datsevich, L., Jess, A., Lauter, A., Schmitz, C., \& Wasserscheid, P. (2001). Deep Desulfurization of Diesel Fuel by Extraction with Ionic Liquids. Chem Commun., 2494.

[13] Liu, Z. C., Hu, J. R., \& Gao, J. S. (2006). FCC naphtha desulfurization via alkylation process over ionic liquid catalyst. Petroleum Proc. Petrochem., 37(10), 22-26.

[14] Alonso, L., Arce, A., Francisco, M., \& Soto, A. (2008). Solvent Extraction of Thiophene from n-Alkanes $\left(\mathrm{C}_{7}, \mathrm{C}_{12}\right.$, and $\left.\mathrm{C}_{16}\right)$ Using the Ionic Liquid $\left[\mathrm{C}_{8} \mathrm{mim}\right]\left[\mathrm{BF}_{4}\right]$. J Chem Thermodyn., 40(6), 966-972. 
[15] Qiu, J., Wang, G., Zeng, , Tang, D. Y., Wang, M., \& Li, Y. (2009). Oxidative desulfurization of diesel fuel using amphiphilic quaternary ammonium phosphomolybdate catalysts. Fuel Process. Technol., 90(12), 538-1542.

[16] Zhang, J., Huang, C. P., Chen, B. H., Li, Y. X., \& Qiao, C. Z. (2007). Extractive Desulfurization from Gasoline by [BMIM] $\left[\mathrm{Cu}_{2} \mathrm{Cl}_{3}\right]$. J Fuel Chem Tech., 33(4), 431-434.

[17] Lu, H. Y., Gao, J. B., Jiang, Z. X., Jing, F., Yang, Y. X., Wang, G., \& Li, C. (2006). UltraDeep Desulfurization of Diesel by Selective Oxidation With $\left[\mathrm{C}_{18} \mathrm{H}_{37} \mathrm{~N}\left(\mathrm{CH}_{3}\right)_{3}\right]_{4}\left[\mathrm{H}_{2} \mathrm{NaPW}_{10} \mathrm{O}_{36}\right]$ Catalyst Assembled in Emulsion Droplets. J Catal, 239(2), 369-375.

[18] Zhao, D. S., Liu, R., Wang, J. L., \& Liu, B. Y. (2008). Photochemical Oxidation ionic Liquid Extraction Coupling Technique in Deep Desulphurization of Light Oil. Energy Fuel, 22(2), 1100.

[19] Jiang, X. C., Nie, Y., Li, C. X., \& Wang, Z. H. (2008). Imidazolium-Based Alkylphosphate Ionic Liquids: A Potential Solvent for Extractive Desulfurization of Fuel. Fuel, 87(1), 79-84.

[20] Yansheng, C., Changping, L., Qingzhu, J., Qingshan, L., Peifang, Y., Xiumei, L., \& Welz-Biermann, U. (2011). Desulfurization by Oxidation Combined with Extraction Using Acidic Room-Temperature Ionic Liquids. Green Chem., 13, 1224-129.

[21] Zhu, W. S., Li, H. M., Gu, Q. Q., Wu, P. W., Zhu, G. P., Yan, S., \& Chen, Y. (2011). Kinetics and mechanism for oxidative desulfurization of fuels catalyzed by peroxomolybdenum amino acid complexes in water-immiscible ionic liquids. J. Mol. Catal. A: Chem., 336(1-2), 16-22.

[22] Nie, Y., Li, C. X., Sun, A. J., Meng, H., \& Wang, Z. (2006). Extractive Desulfurization of Gasoline Using Imidazolium-Based Phosphoric Ionic Liquids. Energy Fuels, 20(5), 2083.

[23] Zhu, H. P., Yang, F., Tang, J., \& He, M. Y. (2003). Brønsted Acidic Ionic Liquid 1Methylimidazolium Tetrafluoroborate: A Green Catalyst and Recyclable Medium for Esterification. Green Chem, 5, 38-39.

[24] Zhang, S., \& Zhang, Z. (2002). Novel Properties of Ionic Liquids in Selective Sulfur Removal from Fuels at Room Temperature. Green Chem, 4, 376-379.

[25] Holbrey, J. D., Reichert, W. M., Nieuwenhuyzen, M., Sheppard, O., Hardacre, C., \& Rogers, R. D. (2003). Liquid Clathrate Formation in Ionic Liquid-Aromatic Mixtures. Chem Commun, 4, 476-477.

[26] Zhao, DS. , Sun, Z. M., Li, F. T., Liu, R., \& Shan, H. D. (2008). Oxidative Desulfurization of Thiophene Catalyzed by $\left(\mathrm{C}_{4} \mathrm{H}_{9}\right)_{4} \mathrm{NBr} 2 \mathrm{C}_{6} \mathrm{H}_{11} \mathrm{NO}$ Coordinated Ionic Liquid. Energy Fuels, 22(5), 3065-3069. 
[27] Zhu, W. S., Li, H. M., Jiang, X., Yan, Y. S., Lu, J. D., \& Xia, J. X. (2007). Oxidative Desulfurization of Fuels Catalyzed by Peroxotungsten and Peroxomolybdenum Complexes in Ionic Liquids. Energy Fuels, 21(5), 2514.

[28] He, L. N., Li, H. M., Zhu, W. S., Guo, J. X., Jiang, X., Lu, J. D., \& Yan, Y. S. (2008). Deep Oxidative Desulfurization of Fuels Using Peroxophosphomolybdate Catalysts in Ionic Liquids. Ind. Eng. Chem. Res., 47(18), 6890-6895.

[29] Lu, L., Cheng, S. F., Gao, J. B., Gao, G. H., \& He, M. Y. (2007). Deep Oxidative Desulfurization of Fuels Catalyzed by Ionic Liquid in the Presence of $\mathrm{H}_{2} \mathrm{O}_{2}$. Energy Fuels, 21(1), 383-384.

[30] Zhao, D. S., Wang, J. L., \& Zhou, E. P. (2007). Oxidative desulfurization of diesel fuel using a Brønsted acid room temperature ionic liquid in the presence of $\mathrm{H}_{2} \mathrm{O}_{2}$. Green Chem., 9, 1219.

[31] Holbrey, J. D., López-Martin, I., Rothenberg, G., Silveiro, G., \& Zheng, X. (2008). Desulfurisation of Oils Using Ionic Liquids: Selection of Cationic and Anionic Components to Enhance Extraction Efficiency. Green Chem., 10, 87-92.

[32] Gao, H., Li, Y., Wu, Y., Luo, M., Li, Q., \& Xing, J. (2009). Extractive Desulfurization of Fuel Using 3-Methylpyridinium-Based Ionic Liquids. Energy Fuels, 23(5), 2690-2694.

[33] Gao, H. S., Luo, M. F., Xing, J. M., Wu, Y., Li, Y. G., Li, W. L., Liu, Q. F., \& Liu, H. Z. (2008). Desulfurization of Fuel by Extraction with Pyridinium-Based Ionic Liquids. Ind. Eng. Chem. Res., 47(21), 8384-8388.

[34] Ristovski, Z. D., Jayaratne, E. R., Lim, M., Ayoko, G. A., \& Morawska, L. (2006). Influence of diesel fuel sulfur on nanoparticle emissions from city buses. Environ Sci.Technol., 40(4), 1314.

[35] Oh, S. K., Baik, D. S., \& Han, Y. C. (2003). Emission characteristics in ultra low sulfur diesel. Int. J. Automot. Technol., 4(2), 95-100.

[36] Demonstration of Advanced Emission Control Technologies Enabling Diesel powered Heavy-duty Engines to Achieve Low Emission levels. (1999). Final Report, Manufacturers of Emission Controls Association, Washington, DC 20036.

[37] California Air Resources Board. (2000, October). Fuels Report: Appendix to the Diesel Risk Reduction Plan, Appendix IV, http://www.arb.ca.gov/diesel/documents/ rrpfinal.pdf.

[38] Iranian Research Institute of Petroleum, Industry. (2000). http://www.ripi.ir/ index.php?option=content\&task=view\&id=61, accessed July 2000.

[39] Gates, B. C., \& Topsoe, H. (1997). Reactivities in Deep Catalytic Hydrodesulfurization: Challenges, opportunities, and the importance of 4-methyldibenzothiophene and 4,6-Dimethyldibenzothiophene. Polyhedron, 16(18), 3213-3217. 
[40] Gray, K. A., Mrachko, C. T., \& Squires, C. H. (2003). Biodesulfurization of fossil fuels. Curr Opin Microbiol., 6(3), 229-235.

[41] Gray, K. A., Pogrebinsky, O. S., Mrachko, G. T., Xi, L., Monticello, D. J., \& Squires, C. H. (1996). Molecular Mechanisms of Biocatalytic Desulfurization of Fossil fuels. Nat. Biotechnol., 14(13), 1705.

[42] Gupta, N., Roychoudhury, P. K., \& Deb, J. K. (2005). Biotechnology of Desulfurization of Diesel: Prospects and Challenges. Appl. Microbiol. Biotechnol., 66(4), 356-366.

[43] Kilbane, J. J. (2006). Microbial Biocatalyst Developments to Upgrade Fossil Fuels. Curr Opin. Microbiol., 17(3), 1-10.

[44] Lee, W. C., Ohshiro, T., Matsubara, T., Izumi, Y., \& Tanokura, M. (2006). Crystalstructure and Desulfurization Mechanism of 2-hydroxybiphenyl-2-Sulfinic Acid Desulfinase. J Biol Chem., 281(43), 32534-32539.

[45] Li, G., Ma, T., Li, J., Liang, F., \& Liu, R. (2006). Desulfurization of Dibenzothiophene by Bacillus Subtilis Recombinants Carrying dszABC and dszD Genes. Biotechnol Lett., 28(14), 1095-1100.

[46] Martín, A. B., Alcón, A., Santos, V. E., \& Garcia-Ochoa, F. (2004). Production of a Biocatalyst of Pseudomonas Putida CECT5279 for Dibenzothiophene (DBT Biodesulfurization for Different media Composition. Energy and Fuels, 18(3), 851-857.

[47] Martín, A. B., Alcón, A., Santos, V. E., \& Garcia-Ochoa, F. (2005). Production of a Biocatalyst of Pseudomonas Putida CECT5279 for Dibenzothiophene (DBT): influence of the Operational Conditions. Energy and Fuels, 19, 775-782.

[48] Monticello, D. J. (2000). Biodesulfurization and the Upgrading of Petroleum Distillates. Curr. Opin. Biotechnol., 11(6), 540-546.

[49] Noda, K. I., Watanabe, K., \& Maruhashi, K. (2003). Recombinant Pseudomonas Putida Carrying Both the dsz and hcu Genes Can Desulfurize Dibenzothiophene in nTetradecane. Biotechnol. Lett., 25(14), 147-150.

[50] Piddington, C. S., Kovacevich, B. R., \& Rambosek, J. (1995). Sequence and Molecular Characterization of a DNA Region Encoding the Dibenzothiophene Desulfurization Operon of Rhodococcus Sp. Strain IGTS8. Appl. Environ. Microbiol., 61(2), 468-475.

[51] Soleimani, M., Bassi, A., \& Margaritis, A. (2007). Biodesulfurization of Refractory Organic Sulfur Compounds in Fossil Fuels. Biotechnol. Adv., 25(6), 570-596.

[52] Xu, P., Yu, B., Li, F. L., Cai, X. F., \& , C. Q. (2006). Microbial degradation of sulfur, nitrogen and oxygen heterocycles. Trends Microbiol., 14, 398-405.

[53] Te, M., Fairbridge, C., \& Ring, Z. (2001). Oxidation Reactivities of Dibenzothiophenes in Polyoxometalate $/ \mathrm{H}_{2} \mathrm{O}_{2}$ and Formic acid $/ \mathrm{H}_{2} \mathrm{O}_{2}$ Systems. Appl. Catal. A: Gen., 219(1-2), 267-280.

[54] Mondal, S., Hangun-Balkir, Y., Alexandrova, L., Link, D., Howard, B., Zandhuis, P., Cugini, A., Horwitz, B., \& Collins, T. J. (2006). Oxidation of Sulfur Components in 
Diesel Fuel Using Fe-TAML® Catalysts and Hydrogen Peroxide. Catal. Today, 116(4), 554-561.

[55] García-Gutiérrez, J. L., Fuentes, G. A., Hernández-Terán, M. E., García, P., MurrietaGuevara, F., \& Jiménez-Cruz, F. (2008). Ultra-Deep Oxidative Desulfurization of Diesel Fuel by the Mo/AlO3- $\mathrm{H}_{2} \mathrm{O}_{2}$ System: The Effect of System Parameters on Catalytic Activity. Appl Catal A: Gen, 334(1-2), 366-373.

[56] Hulea, V., Fajula, F., \& Bousquet, J. (2001). Mild Oxidation With $\mathrm{H}_{2} \mathrm{O}_{2}$ over Ti-Containing Molecular Sieves-a Very Efficientmethod for Removing Aromatic Sulfur Compounds from Fuels. J. Catal., 198(2), 179-186.

[57] Anisimov, A. V., Fedorova, E. V., Lesnugin, A. Z., Senyavin, V. M., Aslanov, L. A., Rybakov, V. B., \& Tarakanova, A. V. (2003). Vanadiumperoxocomplexes as Oxidation Catalysts of Sulfur Organic Compounds by Hydrogen Peroxide in bi-phase Systems. Catal. Today, 78(1-4), 319-325.

[58] Palomeque, J., Clacens, J. M., \& Figueras, F. (2002). Oxidation of Dibenzothiophene by Hydrogen Peroxide Catalyzed by Solid Bases. J. Catal., 211(1), 103-108.

[59] Yazu, K., Yamamoto, Y., Furuya, T., Mild, K., \& Ukegawa, K. (2001). Oxidation of Dibenzothiophenes in an Organic Biphasic System and its Application to Oxidative Desulfurization of Light Oil. Energy Fuels, 15(6), 535-536.

[60] Djangkung, S., Murti, S., Yang, H., Choi, K., Kora, Y., \& Mochida, I. (2003). Influences of Nitrogen Species on the Hydrodesulfurization Reactivity of a Gas Oil Over Sulfide Catalysts of Variable Activity. Appl. Catal. A: Gen., 252(2), 331-346.

[61] Shiraishi, Y., Naito, T., \& Hirai, T. (2003). Vanadosilicate Molecular Sieve as a Catalyst for Oxidative Desulfurization of Light Oil. Ind Eng Chem Res., 42(24), 6034-6039.

[62] Song, C., \& Ma, X. (2003). New Design Approaches to Ultra-Clean Diesel Fuels by Deep Desulfurization and Deep Dearomatization. Appl. Catal. B., 41(1-2), 207-238.

[63] Zhao, D., Wang, Y., Duan, E., \& Zhang, J. (2010). Oxidation Desulfurization of Fuel using Pyridinium-Based Ionic Liquids as Phase-Transfer Catalysts. Fuel Proces Tech., 91(12), 1803.

[64] Arce, A., Francisco, M., \& Soto, A. (2010). Evaluation of the Polysubstituted Pyridinium Ionic Liquid [hmmpy][ $\left.\mathrm{Ntf}_{2}\right]$ as a Suitable Solvent for Desulfurization: Phase Equilibria. J. Chem. Thermodynamics, 42(6), 712-718.

[65] Wang, J. L., Zhao, D. S., Zhou, E. P., \& Dong, Z. (2007). Desulfurization of Gasoline by Extraction with N-alkyl-Pyridinium-Based Ionic Liquids. Journal of Fuel Chemistry and Technology, 35(3), 293-296.

[66] Khupse, N. D., \& Kumar, A. (2010). Contrasting Thermosolvatochromic Trends in Pyridinium-, Pyrrolidinium-, and Phosphonium-Based Ionic Liquids. J. Phys. Chem. $B, 114(1), 376-381$. 
[67] Nie, Y., Li, C., Meng, H., \& Wang, Z. N. (2008). N-Dialkylimidazolium Dialkylphosphate Ionic Liquids: Their Extractive Performance for Thiophene Series Compounds from Fuel Oils Versus the Length of Alkyl Group. Fuel Proces Tech., 8(9), 10-978.

[68] Zhang, S., Zhang, Q., \& Zhang, Z. C. (2004). Extractive Desulfurization and Denitrogenation of Fuels Using Ionic Liquids. Ind Eng Chem Res., 43(2), 614-622.

[69] Yuuki, M., \& Katsuyasu, S. (2008). Removal of Organic Sulfur from Hydrocarbon Resources Using Ionic Liquids. Energy \& Fuels, 22(5), 3303-3307.

[70] Yu, G., Li, X., Liu, X., Asumana, C., \& Chen, X. (2011). Deep Desulfurization of Fuel Oils Using Low-Viscosity-Ethyl-3-methylimidazolium Dicyanamide Ionic Liquid. Ind Eng Chem Res, 50(4), 2236-2244.

[71] Xu, D., Zhu, W., Li, H., Zhang, J., Zou, F., Shi, H., \& Yan, Y. (2009). Oxidative Desulfurization of Fuels Catalyzed by V2O5 in Ionic Liquids at Room Temperature. Energy Fuels, 23(12), 5929-5933.

[72] Zhu, W., Huang, W., Li, H., Zhang, M., Jiang, W., Chen, G., \& Han, C. (2011). Polyoxometalate-Based Ionic Liquids as Catalysts for Deep Desulfurization of Fuels. Fuel Processing Technology, 92(10), 1842-1848.

[73] Wang, J., Zhao, D., \& Li, K. (2010). Oxidative Desulfurization of Dibenzothiophene Using Ozone and Hydrogen Peroxide in Ionic Liquid. Energy Fuels., 24(4), 527-529.

[74] Huang, W., Zhu, W., Li, H., Shi, H., Zhu, G., Liu, H., \& Chen, G. (2010). Heteropolyanion-Based Ionic Liquid for Deep Desulfurization of Fuels in Ionic Liquids. Ind. Eng. Chem. Res., 49(19), 8998-9003.

[75] Ge, J., Zhou, Y., Yang, Y., \& Xue, M. (2011). Catalytic Oxidative Desulfurization of Gasoline Using Ionic Liquid Emulsion System. Ind. Eng. Chem. Res., 50(24), 13686-13692.

[76] Ko, N. H., Lee, J. S., Huh, E. S., Lee, H., Jung, K. D., Kim, H. S., \& Cheong, M. (2008). Extractive Desulfurization Using Fe-Containing Ionic Liquids. Energy \& Fuels, 22(3), 687-690.

[77] Li, F. T., Liu, Y., Sun, Z. M., Chen, L. J., Zhao, D. S., Liu, R. H., \& Kou, C. G. (2010). Deep Extractive Desulfurization of Gasoline with $x \mathrm{Et}_{3} \mathrm{NHCl}_{3} \mathrm{FeCl}_{3}$ Ionic Liquids. Energy Fuels, 24(8), 4285-4289.

[78] Wang, X., Wan, H., Han, M., Gao, L., \& Guan, G. (2012). Removal of Thiophene and Its Derivatives from Model Gasoline Using Polymer-Supported Metal Chlorides Ionic Liquid Moieties. Ind. Eng. Chem. Res., 51(8), 3418-3424.

[79] Zhao, D. S., Sun, Z. M., Li, F. T., \& Shan, H. D. (2009). Optimization of oxidative desulfurization of dibenzothiophene using acidic ionic liquid as catalytic solvent. J Fuel Chem Technol, 37(2), 194-198. 
[80] Zhang, W., Ke, X., Qian, Z., Daliang, L., Shuyao, W., Francis, V., \& Xi-Ming, S. (2010).

Oxidative Desulfurization of Dibenzothiophene Catalyzed by Ionic Liquid [BMIm] $\mathrm{HSO}_{4}$. Ind Eng Chem Res., 49(22), 11760-11763.

[81] Yu, G., Zhao, J., Song, D., Asumana, C., Zhang, X., \& Chen, X. (2011). Deep Oxidative Desulfurization of Diesel Fuels by Acidic Ionic Liquids. Ind Eng Chem Res, 50(20), 11690-11697. 